Poznańskie Studia Teologiczne 29(2015), s. 225-238.

doi: $10.14746 /$ pst.2015.29.13

\author{
Edward Wiszowaty ${ }^{1}$ \\ Uniwersytet Warmińsko-Mazurski w Olsztynie \\ Wydział Teologii
}

\title{
Technologie informacyjne w warsztacie homilisty
}

Obserwowany we współczesnych czasach szybki i wielokierunkowy postęp cywilizacyjny wywiera coraz większy wpływ na wszystkie dziedziny życia, nie pozostawiając praktycznie niczego poza sferą swego oddziaływania. Jednym $\mathrm{z}$ istotnych elementów tego postępu jest niewątpliwie, do niedawna wręcz niewyobrażalny, rozwój technologii informacyjnych, zazwyczaj, choć nie do końca słusznie, kojarzonych z komputerem i internetem. Do istotnych symptomów tych technologii należy to, że mają one charakter globalny i przekraczają wszelkie granice. Nie ma zakątka na ziemi, a nawet w kosmosie, gdzie można by się bez nich obyć, sięgają po nie zarówno elity naukowe, menadżerskie i polityczne, jak też coraz powszechniej zwykli ludzie. Widomym znakiem swoistej rewolucji $\mathrm{w}$ tej dziedzinie jest telefon komórkowy, który przestał być wyłącznie środkiem łączności i stał się podręcznym komputerem umożliwiającym nie tylko porozumiewanie się, ale również nawiązywanie łączności z najbardziej odległymi miejscami na ziemi przez internet, przesyłanie obrazów, robienie zakupów i wykonywanie mnóstwa innych czynności niezależnie od odległości i niejako „poza czasem”. Również Kościoły, zakony, różnorakie wspólnoty religijne, osoby duchowne i zaangażowani religijnie świeccy coraz częściej sięgają po te narzędzia, szerząc niezmienną w swej istocie Ewangelię Jezusa Chrystusa. Wszystko to niejako wymusza pojawienie się nowych form pracy również w warsztacie współczesnego głosiciela słowa Bożego. W pełni uzasadnione wydaje się zatem pytanie o rolę wspomnianych wyżej technologii w przygotowaniu homilii i pracy homilisty. Określa ono główny problem analiz podjętych w niniejszym opracowaniu. Implikuje też następujące pytania szczegółowe: Jak należy rozumieć termin „technologie informacyjne”? Jakie są cechy charakterystyczne tych technologii i jaka jest ich wartość? W jaki sposób homilista może korzystać z technologii

\footnotetext{
${ }^{1}$ Edward Wiszowaty - ks. prof. dr hab. nauk teologicznych, pracownik Wydziału Teologii Uniwersytetu Warmińsko-Mazurskiego w Olsztynie (Katedra Teologii Pastoralnej i Katechetyki) i Wyższej Szkoły Policji w Szczytnie (Instytut Nauk Społecznych). Zainteresowania badawcze: etyka policji, religijność policjantów, homiletyka, teologia pastoralna.
} 
informacyjnych, przygotowując homilię? Jakie są ograniczenia i zagrożenia z tym związane? Poszukując odpowiedzi na wyżej postawione pytania, trzeba mieć na uwadze istotę homilii. Wszystko to określa ramy merytoryczne analiz podjętych w niniejszym opracowaniu.

\section{Słów kilka o istocie homilii}

Przez całe wieki, z wyjątkiem okresu patrystyki, kazanie było rodzajem nauki na temat prawd wiary i zasad życia moralnego, wygłaszanym podczas niedzielnej lub świątecznej mszy św., którego związek z celebrowaną liturgią był stosunkowo luźny i w zasadzie wyczerpywał się w tym, że wygłaszane było w czasie jej trwania ${ }^{2}$. Jednocześnie w obliczu narastającego kryzysu wiary, zwłaszcza od początku XX wieku, poszukiwano dróg odnowy kaznodziejstwa ${ }^{3}$. W pierwszym etapie tych poszukiwań skoncentrowano się na formie przepowiadania rozumianej nie tyle jako forma stylistyczno-kaznodziejska, ile raczej jako wewnętrzny charakter kazania wynikający z ducha Bożego kaznodziei ${ }^{4}$. W klimacie nadal postępującej laicyzacji życia oraz zanikania praktyk religijnych zrodziło się przekonanie, że dla poprawienia skuteczności przepowiadania nie wystarczy sama refleksja na temat formy kaznodziejskiej, czyli ,jak przepowiadać”, lecz koniecznie należy podjąć problem - co przepowiadać, czyli poddać poważnej refleksji teologicznej zagadnienie treści kaznodziejstwa. Przełomowe znaczenie miało w tym wypadku ukazanie się pracy J.A. Jungmanna Die Frohbotschaft und unsere Glaubensverkündigung (Regensburg 1936). Jej autor wskazywał, że forma i treść przepowiadania, dalekie od Ewangelii, są przyczyną, iż wielu chrześcijan odczuwa swoją wiarę jako ciężar i swoisty gorset ograniczający lub wręcz uniemożliwiający pełnię ludzkiego rozwoju, wbrew temu, co napisał św. Paweł Apostoł: „Ku wolności wyswobodził nas Chrystus” (Ga 5,1). Rozwój naukowej egzegezy umożliwił odkrycie specyficznego charakteru słowa Bożego (dabar Jahwe), zwracając przede wszystkim uwagę na jego skuteczność. Spowodowało to swoisty przewrót $\mathrm{w}$ dotychczas obowiązującej koncepcji przepowiadania i w efekcie pozwoliło powrócić do form głoszenia Dobrej Nowiny właściwych wczesne-

${ }^{2}$ Zob. na ten temat np. B. Migut, Kazanie, w: Encyklopedia katolicka, t. 8, red. A. Szostek, B. Migut, E. Gigilewicz [i in.], Lublin 2000, kol. 1265; A. Lewek, Kazanie. Historia, w: Encyklopedia katolicka, t. 8, dz. cyt., kol. 1265-1266.

${ }^{3}$ Impuls do tych poszukiwań stanowiło ogłoszenie nowego Kodeksu prawa kanonicznego, który głoszenie kazań określił jako „gravissimum officium” - najpoważniejszy obowiązek (CIC, can. 1329), a później encyklika Benedykta XV Humani generis redemptionem, nazywana wówczas „wielką kartą kaznodziejstwa”.

${ }^{4}$ Zob. np. A. Lewek, Współczesna odnowa kaznodziejstwa, z. 1: Z najnowszych dziejów ruchu homiletycznego, Warszawa 1980, s. 22-28; K. Panuś, Zarys historii kaznodziejstwa w Kościele katolickim, cz. 1: Kaznodziejstwo w Kościele powszechnym, Kraków 1999, s. 424-433. 
mu chrześcijaństwu i patrystyce ${ }^{5}$. W wyniku tego długiego procesu homilia została uznana za pierwszą „,spośród licznych form przepowiadania”. Sobór Watykański II dostrzegł w niej wręcz „część samej liturgii”" tym samym dając do zrozumienia, że jest miejscem spotkania ze zbawiającym Chrystusem $^{8}$. Potwierdza to najnowsze Dyrektorium homiletyczne ogłoszone przez Kongregację ds. Kultu Bożego i Dyscypliny Sakramentów, gdzie czytamy, że homilia nieodłącznie należy do liturgii, jest nie tylko pouczeniem, lecz także aktem liturgicznym ${ }^{9}$. Ten ścisły związek homilii z liturgią powoduje, że homilia powinna być wygłaszana przez kapłana celebrującego święte misteria. Po długich wiekach kaznodziejskiego moralizatorstwa, doktrynalizmu i dydaktyzmu, homilia - jako akt przepowiadania - zgodnie z naturą słowa Bożego stała się ponownie skutecznym i czytelnym znakiem łaski i zbawienia ${ }^{10}$. Jeśli zatem określa się niekiedy homilię jako jedno z najdonioślejszych teologicznych odkryć minionego wieku, nie ma $\mathrm{w}$ tym żadnej przesady ${ }^{11}$. W dobie nowej ewangelizacji kaznodzieje powinni więc skupić swoją uwagę na tej formie przepowiadania, która z jednej strony pozwala zajaśnieć słowu Bożemu z całą jego mocą, z drugiej zaś odkrywa przed samym człowiekiem to wszystko, co stanowi dramatyczny (niekiedy wręcz tragiczny) wymiar jego egzystencji, powodujący, że sam dla siebie pozostaje on wciąż pytaniem bez odpowiedzi ${ }^{12}$. Zarówno $\mathrm{w}$ pierwszym wymiarze, jak i zwłaszcza drugim, wymagającym współbycia ze współczesnym człowiekiem, doświadczającym cierpienia w nie mniejszym stopniu jak jego przodkowie, technologie informatyczne - wykorzystane zgodnie z ich naturą i w sposób krytyczny - mogą służyć zaangażowanemu homiliście nieocenioną pomocą. Potwierdza to Dyrektorium homiletyczne, przywołując tekst adhortacji apostolskiej papieża Franciszka: „Jedną z rzeczy najważniejszych jest nauczenie się posługiwania w przepowiadaniu obrazami, czyli przemawiania obrazami. Czasem używa się przykładów, aby uczynić bardziej zrozumiałym coś, co chce się wyjaśnić, ale te

\footnotetext{
${ }^{5}$ Szerzej na ten temat zob. E. Wiszowaty, Od kazania tematycznego do homilii, „Studia Warmińskie" 39 (2002), s. 385-394.

${ }^{6}$ Paweł VI, Evangelii nuntiandi, 43.

${ }^{7}$ Konstytucja o liturgii świętej Sacrosanctum Concilium, [dalej KL] Sobór Watykański II, Konstytucje, dekrety, deklaracje, tekst polski, nowe thumaczenie, Poznań 2002, nr 52.

${ }^{8}$ Warto zauważyć, że w podobny sposób rozumiał homilię Orygenes: jest to wydarzenie zbawcze, polegające na spotkaniu uczestników liturgii z Chrystusem obecnym w Piśmie Świętym. Por. E. Staniek, Kazanie w starożytności chrześcijańskiej, w: Fenomen kazania, red. W. Przyczyna, Kraków 1994, s. 19.

${ }^{9}$ Por. Kongregacja ds. Kultu Bożego i Dyscypliny Sakramentów, Dyrektorium homiletyczne (tłum. pol. P. Borkowski) - tekst nieoficjany (komputeropis), $\mathrm{nr} 4$.

${ }^{10} \mathrm{~W}$ tym znaczeniu przepowiadanie ma wymiar sakramentalny.

${ }^{11}$ P. Duployé, Rhetorik und Gotteswort, Düsseldorf 1957, s. 65; por. K. Panuś, Zarys historii kaznodziejstwa w kościele katolickim, cz. 1: Kaznodziejstwo w Kościele powszechnym, dz. cyt., s. 477.

${ }^{12}$ E. Wiszowaty, Od kazania tematycznego do homilii, art. cyt., s. 394.
} 
przykłady często odnoszą się tylko do rozumowania; natomiast obrazy pomagają w docenieniu i przyjęciu przesłania, które chcemy przekazać. Atrakcyjny obraz sprawia, że przesłanie jest odczuwane jako coś swojskiego, bliskiego, możliwego, powiązanego z naszym życiem. Trafny obraz może doprowadzić do zasmakowania w przesłaniu, które pragniemy przekazać, budzi pragnienie i motywuje wolę ku Ewangelii"'13.

\section{Wyjaśnienie terminu, ,technologie informacyjne"}

Obok homilii centralną kategorię niniejszego opracowania stanowią technologie informacyjne. Analiza różnych materiałów poświęconych tej tematyce wskazuje, że często termin ,technologie informacyjne" postrzegany jest w kontekście edukacji szkolnej ${ }^{14}$ i kształcenia ustawicznego ${ }^{15}$. Niejednokrotnie rozpatruje się go w powiązaniu z życiem osobistym, indywidualnym i społecznym oraz z aktywnością zawodową ${ }^{16}$. Zwraca się przy tym uwagę na częstotliwość i sposób korzystania z technologii informacyjnych, rozpatrując te kwestie w kontekście przemian cywilizacyjnych i uwarunkowań społeczno-kulturowych ${ }^{17}$.

Analizując dorobek wielu polskich autorów ${ }^{18}$ podejmujących problemy związane z technologiami informacyjnymi, zauważa się częste odwołania do angielskiego słowa information technology i stosowanie skrótu IT. Zgodnie twierdzą oni, że znaczenie tego terminu zawiera różne elementy związane z informatyką

${ }^{13}$ Kongregacja ds. Kultu Bożego i Dyscypliny Sakramentów, Dyrektorium homiletyczne, dz. cyt., 31; Franciszek, Evangelii gaudium, 157.

${ }^{14}$ Zob. np. publikacje zamieszczone w: Technologie informacyjno-komunikacyjne $w$ procesie kształcenia, red. J. Jędryczkowski, Jelenia Góra 2011; Technologie informacyjno-komunikacyjne w edukacji XXI wieku, red. R. Wawer, M. Pakuła, Lublin 2014.

${ }^{15}$ Zob. np. Technologie informacyjne a zmiany współczesnej edukacji, red. S. Kuruliszwili, Kraków 2014; Technologie informacyjne i komunikacyjne w edukacji dorostych: przewodnik dobrych praktyk, red. I. Moczydłowska, Siedlce 2012.

${ }^{16}$ Dla przykładu można wskazać następujące opracowania: Technologie informacyjne dla spoteczeństwa, red. W. Chmielarz, T. Parys, Warszawa 2009; Technologie informacyjno-komunikacyjne w pracy stużb społecznych, red. E. Harlow, S.A. Webb, Warszawa 2014; Technologie informacyjne w edukacji policjantów, red. A.W. Mitasa, Legionowo 2008; Technologie informacyjne $w$ funkcjonowaniu organizacji: zarzadzanie z wykorzystaniem multimediów, red. L. Kiełtyka, Toruń 2013.

${ }^{17}$ Zob. np. W. Paja, Technologie internetowe - wybrane zastosowania, Rzeszów 2012; B. Stachowiak, Technologie informacyjno-komunikacyjne $w$ funkcjonowaniu uczelni wyższych, Toruń 2012.

${ }^{18}$ Zob. np. J. Bartoszek, Technologie informacyjne w edukacji przyszłości, „Prakseologia” (2005) $\mathrm{nr}$ 145, s. 141-149; M. Orzoł, Znaczenie współczesnych technologii informacyjnych dla zarzqdzania polskimi przedsiębiorstwami, http://www.ptzp.org.pl/files/konferencje/kzz/arty k_pdf_2010/117_Orzol_I.pdf [dostęp: 28.04.2015], s. 1-2; M. Ścigała, Technologie informacyjne determinanta innowacyjności: aktualny model organizacji, „Zeszyty Naukowe. Organizacja i Zarządzanie / Politechnika Śląska” 68 (2014), s. 413-423; 
i pokrewnymi technologiami, takimi jak: informacja, komputery, informatyka i telekomunikacja ${ }^{19}$. Najogólniej termin ,technologia informacyjna” wskazuje na całokształt, zespół środków, czyli urządzeń typu komputery, sieci komputerowe, media oraz narzędzi w postaci oprogramowania, a także technologii służących wszechstronnemu pozyskiwaniu i przetwarzaniu informacji ${ }^{20}$. Powyższe określenie badacze zagadnienia uszczegóławiają ${ }^{21}$. W związku z tym niemal zgodnie twierdza, że termin „technologie informacyjne” wskazuje nie tylko na elementy informatyki, lecz także na działania związane z poszukiwaniem i gromadzeniem informacji, jej zapisywaniem, zabezpieczaniem, przechowywaniem, przetwarzaniem, prezentowaniem, przesyłaniem i likwidacją ${ }^{22}$. Takie określenie wydaje się znaczące dla niniejszego opracowania. Nie ogranicza się jedynie do zespołu nowoczesnych urządzeń, które są wykorzystywane w procesie komunikowania (np. do komputerów, sieci komputerowych i najnowszych oprogramowań komputerowych). Przeciwnie, wskazuje na efektywne stosowanie środków i narzędzi oraz źródeł informacji w celu przeprowadzenia analizy i syntezy informacji. Za istotne uznaje przetwarzanie, selekcjonowanie, tworzenie spójnego obrazu z elementów informacyjnych umieszczonych w różnych źródłach, których wykorzystanie staje się możliwe jedynie za pomocą środków i metod informatyki.

Wyżej opisane rozumienie technologii informacyjnych stanowi zatem punkt odniesienia dla analiz, które zostaną przeprowadzone poniżej. Uwzględnia bowiem wszystkie aspekty istotne dla warsztatu pracy głosiciela słowa Bożego. Wyraźnie wskazuje na narzędzia, za pomocą których może on pozyskiwać informacje, selekcjonować je, analizować, przetwarzać, gromadzić i zarządzać po to, by w akcie przepowiadania przekazywać je słuchaczom słowa Bożego.

\section{Charakterystyka technologii informacyjnych i ich wartość}

Technologie informacyjne stanowią główną dziedzinę informatyki ${ }^{23}$. Najczęściej bywają utożsamiane $\mathrm{z}$ komputerem ${ }^{24}$, chociaż oprócz tego wymienia się

${ }^{19}$ M. Orzoł, Znaczenie wspótczesnych technologii..., art. cyt., s. 1-2.

${ }^{20}$ Tamże.

${ }^{21}$ Tamże; H. Batorowska, Technologia informacyjna w kształceniu ogólnym. Wybrane zagadnienia dla dyrektorów, nauczycieli i bibliotekarzy szkolnych, Kraków 2001; K. Mikulski, Technologia informacyjna w administracji i dla administracji, Bydgoszcz 2008.

${ }^{22}$ Szerzej o tym można znaleźć np. w: A. Breczko, Rozwój technologii informacyjnej: nowe wyzwania prawa i moralności w XXI wieku, „Administracja Publiczna” 1 (2011), s. 151-162; R. Kołodziejczyk, Technologia informacyjna, Kielce 2011; tenże, Technologia informacyjna - nowa gałaź wiedzy, „Zeszyty Wszechnicy Świętokrzyskiej” 21 (2004), s. 103-115; M. Orzoł, Znaczenie wspótczesnych technologii informacyjnych dla zarzq̨dzania polskimi przedsiębiorstwami, art. cyt., s. 1-2; Technologia informacyjna w społeczeństwie wiedzy, red. J. Trawka, Katowice 2005.

${ }^{23}$ Zob. np. M. Adamski, Informatyka - nauka, sztuka, czy rzemiosło?, http://www.uz.zgora.pl/ wydawnictwo/miesiecznik11-2002/17.pdf [dostęp: 29.04.2015], s. 1-4.

${ }^{24}$ Zob. o tym np. w: W. Sikorski, Komputer, Warszawa 2010. 
również inny sprzęt komputerowy, np. laptopy, tablety, przenośne urządzenia telefoniczne łączące w sobie funkcje telefonu komórkowego i komputera kieszonkowego, czyli smartfony, drukarki, skanery, projektory multimedialne oraz akcesoria komputerowe (np. myszkę, klawiaturę, monitor) i nośniki danych (np. zewnętrzne karty pamięci, płyty CD i DVD) niezbędne w efektywnej pracy ${ }^{25}$. Za znaczące uznaje się również wszelkiego rodzaju oprogramowania komputerowe, które pozwalają człowiekowi wykonywać pracę na komputerze ${ }^{26}$. Stanowią one niezastąpiony element technologii informacyjnej. Bez nich niemożliwe byłoby automatyczne przetwarzanie danych za pomocą komputera czy też wykorzystanie oraz prezentowanie obrazu statycznego, dźwięku, hipertekstu, obrazu dynamicznego (wideo) i różnego rodzaju animacji ${ }^{27}$.

Wśród charakterystycznych, a zarazem istotnych cech technologii informacyjnych, wymienia się interaktywność. Komputer połączony z ogólnoświatową siecią komputerowa, zwaną w formie skróconej (od angielskiego inter-network, dosłownie „między-sieć”) internetem, umożliwia szybki dostęp do informacji pochodzących z różnych źródeł ${ }^{28}$. Innymi słowy, technologia informacyjna pomaga w pozyskiwaniu wiadomości na określony temat. Pozwala też współtworzyć informacje. W internecie nie ma bowiem wyraźnej różnicy między nadawcą a odbiorcą ${ }^{29}$. Użytkownicy mogą współtworzyć serwisy internetowe (np. wpisując komentarze pod publikacją) oraz oceniać użyteczność internetowych serwisów informacyjnych, stron i aplikacji ${ }^{30}$. Poza tym dobrze skonstruowane strony www dają czytelnikom różne możliwości w zakresie kontaktu $\mathrm{z}$ ich twórcami. Służy temu zarówno poczta elektroniczna, jak też rozmowy prowadzone on-line z innymi użytkownikami czy zapraszanymi gośćmi ${ }^{31}$. W praktyce najczęściej dokonuje się to za pomocą usług chat i forum ${ }^{32}$. Zawsze też każdy kontakt człowieka ze stroną www za pośrednictwem łączy internetowych pozostawia ślad. Korzystając z serwisów internetowych, można za pomocą samodzielnej wyszukiwarki (np. Google, Netsprint, Szukacz, AltaVista) lub wyszukiwarki wbudowanej w strukturę polskich portali (np. wp.pl, onet.pl, interia.pl) czy też z wyszu-

${ }^{25}$ Tamże.

${ }^{26}$ Tamże.

${ }^{27}$ Tamże.

${ }^{28}$ Warto przypomnieć, że w znaczeniu informatycznym internet stanowi przestrzeń adresów IP, które zostały przydzielone hostom i serwerom połączonym za pomocą urządzeń sieciowych (np. kart sieciowych, modemów, koncentratorów), które komunikują się za pomocą protokołu internetowego z wykorzystaniem infrastruktury telekomunikacyjnej (np. łącza przewodowego lub bezprzewodowego). Zob. np. K. Żywczak, Internet krok po kroku. Praktyczny poradnik, Poznań 2010.

${ }^{29}$ A. Niwiński, Środki informatyczne w katechetycznej działalności Kościoła, Kraków 2004, s. $237,241-242$.

${ }^{30}$ Tamże.

${ }^{31}$ Tamże.

${ }^{32}$ Tamże. 
kiwarki w przeglądarce Internet Explorer i Mozzila Firefox, szybko odnaleźć interesujące użytkownika informacje. Również portale katolickie (np. opoka.org.pl, deon.pl) mają wbudowaną wyszukiwarkę. Jeżeli informacje odnalezione za pomocą wyszukiwarki okażą się użyteczne, można je łatwo skopiować do zbiorów w wersji elektronicznej czy też za pomocą poczty elektronicznej rozesłać do innych odbiorców. W ten sposób gromadzenie informacji staje się łatwe, szybkie i tanie. Co ważne, pozyskiwane dane są aktualne, a przez to nie tylko wzbogacają osobistą wiedzę użytkownika internetu, lecz także mogą okazać się przydatne w życiu codziennym i w pracy zawodowej ${ }^{33}$. Tak więc technologie informacyjne stanowią narzędzie, za pomocą którego użytkownik jest w stanie pozyskiwać informacje, selekcjonować, przetwarzać, zarządzać nimi oraz przekazywać je innym ludziom.

\section{Technologie informacyjne w przygotowaniu homilii}

Nowe technologie informacyjne stają się obecnie jednym z podstawowych narzędzi w przygotowaniu homilii, zwłaszcza dla głosicieli słowa Bożego młodszego pokolenia. Uwidacznia się to szczególnie w poszukiwaniu materiałów, które stanowią źródło i tworzywo kaznodziejskie. Ogólnoświatowa sieć komputerowa ułatwia dostęp nie tylko do nauczania Kościoła, ale również do różnorakich doświadczeń ludzkich, bowiem „homilista - jak stwierdza papież Franciszek powinien także słuchać ludu, aby odkryć to, co wierni powinni usłyszeć. Homilista jest człowiekiem kontemplującym słowo, a także kontemplującym lud"34. Można w niej znaleźć również teksty biblijne zredagowane w różnych językach, co umożliwia porównanie różnych tłumaczeń celem wydobycia pełniejszego sensu tych tekstów. Co więcej, w ogólnoświatowej sieci komputerowej upowszechniane są pomoce kaznodziejskie, zawierające konkretne homilie.

Poszukując inspiracji, homilista może podjać lekturę internetowych zasobów. Wśród różnych portali internetowych z materiałami homiletycznymi przykładowo wymienić można Redemptorystowski Portal Kaznodziejski ${ }^{35}$ i Ekspres Ho-

\footnotetext{
${ }^{33}$ Zob. szerzej o tym np. w: Internet światem człowieka, red. M. Drożdż, J. Smoleń, Kielce 2009.

${ }^{34}$ Franciszek, Evangelii gaudium, 154.

${ }^{35}$ Ten internetowy portal homiletyczny powstał z inicjatywy prowincji warszawskiej ojców redemptorystów. Zawiera on propozycje przepowiadania słowa Bożego podczas liturgii. Słusznie zatem twórcy strony przypominają że „homilia jest wydarzeniem stricte liturgicznym i ten kontekst jest dla niej jak najbardziej naturalny. Stąd też [...] proponowane teksty [mają służyć - E.W.] jedynie jako pewne intuicje pod tworzenie własnych przemówień, uwzględniających cały szereg kontekstów, w których żyją konkretni wierzący w [...] parafiach [...]". Zob. http://www.slowo.redemptor.pl/pl/46758/0/Misja_strony.html; http://www.slowo.redemptor.pl/pl/50170/0/Kazania_i_ homilie_obrzedowe.html [dostęp: 10.05.2015]
} 
miletyczny ${ }^{36}$. Obok tego różne pomoce dla kaznodziejów dostępne są m.in. na portalach wiara ${ }^{37}$, homilie ${ }^{38}$, katolik $^{39}$.

Za błędne trzeba uznać dosłowne kopiowanie z internetu tekstów homilii. Gotowe teksty homilii oraz inne pomoce odgrywają rolę przykładu oraz źródła wspomagającego i dostarczającego tworzywa w twórczym opracowaniu przez kaznodzieję własnej autorskiej homilii. W żadnym wypadku nie zwalniają homilisty z podjęcia osobistego wysiłku w przygotowaniu tekstu, który ma być przepowiadany jako słowo Boże podczas liturgii ${ }^{40}$. Co ważne, nie eliminują poszczególnych etapów pracy nad homilią ${ }^{41}$. Przeciwnie, wymagają rzetelnego podejścia do czynności związanych z przygotowaniem homilii na podstawie nowych technologii informacyjnych ${ }^{42}$. „Przygotowanie przepowiadania słowa jest - jak trafnie zwrócił na to uwagę papież Franciszek - zadaniem tak ważnym, że należy poświęcić dłuższy czas na studium, modlitwę, refleksję i duszpasterską kreatywność [...]”43. Właśnie odpowiednia ilość czasu poświęconego na tę czynność pozwala kaznodziei w sposób aktywny i twórczy przygotować tekst homilii ${ }^{44}$.

Pierwszym i podstawowym etapem jest czytanie słowa Bożego poprzedzone modlitwą do Ducha Świętego i ofiarowaniem siebie Bogu ,jako narzędzie (por. Rz 12,1), ze wszystkimi swoimi zdolnościami, aby Bóg mógł się nim posługiwać”45. To właśnie Duch Święty otwiera serce homilisty, pozwala „zatrzymać się z postawą ucznia: «Mów Panie, bo sługa Twój słucha» (1 Sm 3,9)"46 i sługi słowa oraz pomaga „rozpoznać prawdziwe znaki obecności lub zamysłów Bo-

${ }^{36}$ Portal ten prowadzony jest pod patronatem Wydawnictwa św. Stanisława BM. Adresowany jest do księży, którzy nie mają pomysłu na kazanie. Osoby świeckie zachęcane są do zgłaszania w portalu własnych problemów i współczesnych wydarzeń, które mają inspirować do przygotowania homilii interpretującej je na podstawie słowa Bożego. Zob. http://www.ekspreshomiletyczny.pl/.

${ }^{37}$ Wśród działów tematycznych poświęconych różnym aspektom wiary wyodrębniono zakładkę, w której umieszczane są homilie. Zob. http://liturgia.wiara.pl/Homilie.

${ }^{38}$ Prowadzą go księża zaangażowani w różne formy posługi słowa Bożego (w szkole, w parafii, na wyższych uczelniach). Zob. http://homilie.pl/bn.html.

${ }^{39}$ Jest to katolicki portal z zakładką „kazania”, w którym zamieszcza się teksty homilii. Zob. http://www.kazanie.katolik.pl/.

${ }^{40}$ Zob. np. KL 10.

${ }^{41}$ Szerzej zagadnienia związane z przygotowaniem homilii opisuje np. J. Twardy, Proces przygotowania homilii, ,Roczniki Teologiczne” 61 (2014) z. 12, s. 73-87.

${ }^{42}$ Warto dodać, że Henryk Sławiński w analizach prowadzonych na temat przygotowania homilii za pomocą internetu wyodrębnia trzy etapy: inkubacji, iluminacji i redakcji. Zob. o tym w: H. Sławiński, Przygotowanie homilii i kazania za pomoca internetu, „Ateneum Kapłańskie” 149 (2007), z. 1, s. 125-132. Wcześniej zwrócili uwagę na znaczenie tego procesu w tworzeniu homilii H. Arens, F. Richardt, J. Schulte, Kreativität und Predigtarbeit. Vielseitiger Denken Einfallsreicher Predigen, München 1974, s. 26-33.

${ }^{43}$ Franciszek, Evangelii gaudium, 145.

${ }^{44}$ Tamże.

${ }^{45}$ Tamże.

46 Tamże 146. 
żych"47. On też uzdalnia do spojrzenia na wydarzenia w świecie i doświadczenia adresatów homilii przez pryzmat wiary. Dzięki wsparciu Ducha Świętego można poprawnie interpretować ludzkie życie w świetle słowa Bożego czytanego podczas liturgii. Stąd też istotne jest duchowe przygotowanie połączone z modlitwą homilisty ${ }^{48}$.

$\mathrm{Z}$ uwagi na adresatów homilii uzasadnione wydaje się zbieranie z zasobów internetowych informacji na temat aktualnych wydarzeń i doświadczeń oraz skorzystanie z pomocy, jakie oferuje analiza literacka ${ }^{49}$. Ukonkretniając te czynności, homilista powinien „Zwrócić uwagę na słowa, które się powtarzają lub się wyróżniają, rozpoznać strukturę oraz własny dynamizm tekstu, [czy też - E.W.] wziąć pod uwagę miejsce zajmowane przez występujące osoby itp." ${ }^{50}$. Szczegóły zawarte $w$ tekście nie są jednak najważniejsze. One mogą jedynie pomóc w zrozumieniu głównego przesłania. Właśnie najważniejsze jest „odkrycie głównego przesłania i tego, co tworzy strukturę i jedność tekstu [...], [czyli - E.W.] tego, co autor na pierwszym miejscu chciał przekazać [...], jaki efekt chciał wywołać" 51 . W osiagnięciu tego celu homilista znajduje pomoc w nauczaniu całej Biblii przekazanym przez Kośció ${ }^{52}$. Respektowanie tej zasady interpretacji chroni przed błędną, subiektywną, częściową lub sprzeczną z innymi tekstami biblijnymi proklamacją słowa Bożego.

Kolejny etap pracy nad homilią polega na rozważaniu tekstu biblijnego, poddaniu się słowu Bożemu, czyli na ,personalizacji Słowa"53. Homilista najpierw sam ma stać się słuchaczem słowa Bożego, kontemplującym treści, które głosi, i współpracującym z Bogiem. W tym celu pomocne mogą okazać się udostępniane $\mathrm{w}$ internecie homilie papieskie i konferencje głoszone podczas rekolekcji. Pobudzają one homilistę do refleksji, wzmacniają wiarę i otwierają jego serce na działanie łaski Bożej. Przykładowo wymienić można homilie głoszone przez znanych, kompetentnych i cenionych przez słuchaczy kaznodziejów (np. ks. bpa Edwarda Dajczaka, ks. prof. Edwarda Stańka, o. Leona Knabita, o. Augustyna Pelanowskiego, ks. Piotra Pawlukiewicza). Co więcej, odsłuchany czy też oglądany $\mathrm{w}$ internecie przebieg spotkania homilisty ze słuchaczami może odgrywać ważną rolę. Motywuje bowiem do stawania się autentycznym słuchaczem słowa, otwiera na działanie Ducha Świętego oraz skłania do osobistej modlitwy i przemiany serca, a przez to przyczynia się do stawania się świadkiem Ewangeliii ${ }^{54}$.

\footnotetext{
${ }^{47}$ Paweł VI, Konstytucja duszpasterska o Kościele w świecie współczesnym Gaudium et spes, 11.

${ }^{48}$ Franciszek, Evangelii gaudium, 146.

${ }^{49}$ Tamże 147.

${ }^{50}$ Tamże.

${ }^{51}$ Tamże.

${ }^{52}$ Tamże 148.

${ }^{53}$ Tamże 149.

${ }^{54}$ Tamże 150-151.
} 
W związku z powyższym na uwagę zasługuje również metoda lectio divina, która ,polega [...] na czytaniu słowa Bożego w chwilach modlitwy, by [...] ono oświecało i odnowiło" 55 . To modlitewne czytanie tekstów biblijnych poprzedza studium. Stanowi bowiem punkt wyjścia w przygotowaniu homilii. Pozwala homiliście odczytać osobiste znaczenie orędzia zawartego w tekście i zastosować je we własnym życiu, czyli rozpoznać, co Bóg mówi do homilisty poprzez konkretny tekst oraz do czego zaprasza i do jakich zmian skłania ${ }^{56}$. Chodzi tu o interioryzację słowa Bożego i jego aktualizację w życiu homilisty ${ }^{57}$.

Znajomość tekstów biblijnych, które będą czytane podczas liturgii, nie wystarcza. Niezbędne jest również wsłuchiwanie się w odbiorców - w ich problemy, pragnienia, odczucia, doświadczenia, ograniczenia, poziom życia religijnego oraz jakość więzi z Bogiem i ze wspólnotą Kościoła ${ }^{58}$. Chodzi tu o realne spojrzenie na życie słuchaczy (ich radości i problemy, zwątpienia, kryzysy i nadzieje) oraz ,powiązanie przesłania tekstu biblijnego z ludzką sytuacją z tym, czym ludzie żyją, z doświadczeniem potrzebującym światła" 59 . Korzystając z nowych technologii informacyjnych, homilista może lepiej rozpoznać pragnienia słuchaczy oraz zaznajomić się z aktualnymi wydarzeniami, do których później nawiąże $\mathrm{w}$ homiliii ${ }^{60}$. Dostępne w zasobach internetowych informacje pozwalają też lepiej poznać i zrozumieć odpowiednie, wzbogacone o narzędzia pedagogiczne, sposoby przepowiadania słowa Bożego tak, aby w niczym nie zostało naruszone przesłanie ewangeliczne ${ }^{61}$. W związku z powyższym za istotne uznaje się mówienie zwięźle i obrazowo. Właśnie przemawianie obrazami odgrywa znaczącą rolę w odkryciu przez słuchaczy znaczenia słowa Bożego i przyjęciu go za istotne dla osobistego życia ${ }^{62}$. Pozwala wyrazić ,jedną myśl, jedno uczucie i jeden obraz” ${ }^{\prime 3}$. W szczególnych sytuacjach, gdy na to pozwalają warunki zewnętrzne (np. wyposażenie Kościoła w projektor multimedialny i ekran projekcyjny o dobrze dobranych parametrach, posiadanie w komputerze dobrej jakości obrazów), warto podczas głoszenia słowa Bożego wyświetlić korespondujące $\mathrm{z}$ tym słowem obrazy. Szczególne znaczenie ma to w homiliach podczas mszy św. z udziałem dzieci. Atrakcyjny obraz z komputera podłączonego do projektora, gdy pojawi się na ekranie projekcyjnym, może sprawić, że przesłanie głoszone podczas homilii utrwali się w pamięci słuchaczy, pobudzi ich wyobraźnię, skłoni do refleksji i zmotywuje do życia według słowa Bożego. Stworzy przy tym możliwość

${ }^{55}$ Tamże 152.

${ }^{56}$ Tamże 153.

${ }^{57}$ Tamże.

${ }^{58}$ Tamże 154.

59 Tamże.

${ }^{60}$ Tamże 155.

${ }^{61}$ Tamże 156.

${ }^{62}$ Tamże 157.

${ }^{63}$ Tamże. 
interaktywnego sposobu głoszenia orędzia ewangelicznego, a zarazem uchroni homilistę przed rutyna, a słuchaczy przed zniechęceniem oraz pozornym słuchaniem i zrozumieniem. Poprawi też koncentrację uwagi, konieczną do zapamiętania usłyszanego tekstu homilii. Tym samym może przyczynić się do zwiększenia skuteczności głoszenia słowa Bożego.

\section{Uwagi końcowe}

Powszechny dostęp do technologii informacyjnych sprawia, że mogą one stanowić interesującą i pożyteczną alternatywę dla tradycyjnych form warsztatu pracy homilisty. Dają szansę poszerzania i aktualizowania wiedzy oraz doskonalenia i nabywania nowych umiejętności. Ta szansa wydaje się ważna zwłaszcza dla kapłanów, którzy pracują w parafiach oddalonych od ośrodków teologicznych. Technologie informacyjne pozwalają nie tylko na poznanie nowych treści z zakresu homiletyki i dyscyplin pokrewnych (np. emisji głosu, metodyki skutecznego komunikowania i budowania więzi ze słuchaczami), ale również na wymianę doświadczeń bez zmiany miejsca i ponoszenia większych kosztów. Dostęp do ogólnoświatowej sieci komputerowej pozwala homilistom dzielić się z innymi osobistą wiedzą i doświadczeniem oraz rozwijać kompetencje związane $\mathrm{z}$ pracą nad homilią.

Chcąc efektywnie i zgodnie z naturą homilii posługiwać się technologiami informacyjnymi, należy potraktować je jedynie jako źródło wspomagające i dostarczające tworzywa kaznodziejskiego. Istotne zatem wydaje się umiejętne, a zarazem roztropne wykorzystanie tego narzędzia w warsztacie pracy współczesnego kaznodziei. Technologie informacyjne nie mogą zwalniać homilisty z osobistego przygotowania słowa Bożego, a przez to przyczyniać się do bezrefleksyjnego kopiowania tekstów homilii i odczytywania ich w kościele podczas liturgii słowa.

W związku z powyższym warto zarówno w początkowej, jak i permanentnej formacji kapłanów zwracać większą uwagę na potrzebę respektowania zasady złotego środka w korzystaniu z zasobów internetowych. Pamiętając o zaletach technologii informacyjnych związanych $\mathrm{z}$ warsztatem pracy homilisty, trzeba rozwijać w kaznodziejach krytyczne myślenie oraz kreatywność w przygotowaniu i głoszeniu homilii. Na szczególną uwagę zasługuje przywoływanie sprawdzonych przez pokolenia prostych zasad związanych z procesem tworzenia homilii, a zwłaszcza zwrócenie większej uwagi na duchowość homilisty, jego wiarę i modlitwę oraz na posługiwanie się obrazem i zrozumiałym dla słuchaczy językiem. W ten sposób zostanie zachowana ewangeliczna zasada wydobywania ze skarbca rzeczy nowych i starych ${ }^{64}$.

\footnotetext{
${ }^{64}$ Por. Mt 13,44-52.
} 


\section{Information Technologies in the Homilist's Skills and Tools}

\section{Summary}

The development of information technology has a profound impact on all areas of life without exception. These technologies are tools that enable the user not only to obtain information, select, process and manage it but also pass it on to other people. In the context of the media society also a preacher of the word of God during Sunday and holiday masses cannot ignore the assistance they offer if he wants to avoid the danger that his efforts will be treated as a kind of an open-air museum.

The main thread of the study is therefore an attempt to identify opportunities for the use of these technologies in the homilist's skills and tools because they can provide an interesting and profitable alternative to traditional forms of homiletic expertise. Attention is drawn to the fact that in order to use these technologies efficiently and in accordance with the nature of the homily they should be treated only as a supporting source that provides preaching material.

\section{Keywords}

ccomputer animation, preaching, the homily, imagery, information technologies

\section{Słowa kluczowe}

animacja komputerowa, kaznodziejstwo, homilia, obrazowość, technologie informatyczne

\section{Bibliografia}

Adamski M., Informatyka - nauka, sztuka, czy rzemiosło?, http://www.uz.zgora.pl/wyda wnictwo/miesiecznik11-2002/17.pdf [dostęp: 29.04.2015], s. 1-4.

Arens H., Richardt F., Schulte J., Kreativität und Predigtarbeit. Vielseitiger Denken Einfallsreicher Predigen, München 1974.

Bartoszek J., Technologie informacyjne w edukacji przyszłości, „Prakseologia” (2005) nr 145, s. 141-149.

Batorowska H., Technologia informacyjna w kształceniu ogólnym. Wybrane zagadnienia dla dyrektorów, nauczycieli i bibliotekarzy szkolnych, Kraków 2001.

Breczko A., Rozwój technologii informacyjnej: nowe wyzwania prawa i moralności $w$ XXI wieku, „Administracja Publiczna” 1 (2011), s. 151-162.

Duployé P., Rhetorik und Gotteswort, Düsseldorf 1957.

Paweł VI, Evangelii muntiandi, 43.

Encyklopedia katolicka, t. 8, red. A. Szostek, B. Migut, E. Gigilewicz [i in.], Lublin 2000.

Fenomen kazania, red. W. Przyczyna, Kraków 1994.

Franciszek, Adhortacja apostolska „Evangelii gaudium” o głoszeniu Ewangelii we wspótczesnym świecie, Kraków 2013, wydanie II poprawione.

http://homilie.pl/bn.html.

http://liturgia.wiara.pl/Homilie.

http://www.ekspreshomiletyczny.pl/. 
http://www.kazanie.katolik.pl/.

http://www.slowo.redemptor.pl/pl/46758/0/Misja_strony.html

http://www.slowo.redemptor.pl/pl/50170/0/Kazania_i_homilie_obrzedowe.html

Internet światem człowieka, red. M. Drożdż, J. Smoleń, Kielce 2009.

Kołodziejczyk R., Technologia informacyjna - nowa gałaź wiedzy, „Zeszyty Wszechnicy Świętokrzyskiej” 21 (2004), s. 103-115

Kołodziejczyk R., Technologia informacyjna, Kielce 2011.

Kongregacja ds. Kultu Bożego i Dyscypliny Sakramentów, Dyrektorium homiletyczne, thum. P. Borkowski, tekst nieoficjany (komputeropis), $\mathrm{nr} 4$.

Lewek A., Wspótczesna odnowa kaznodziejstwa, z. 1: Z najnowszych dziejów ruchu homiletycznego, Warszawa 1980.

Migut B., Kazanie, w: Encyklopedia katolicka, t. 8, red. A. Szostek, B. Migut, E. Gigilewicz [i in.], Lublin 2000, kol. 1265.

Mikulski K., Technologia informacyjna $w$ administracji $i$ dla administracji, Bydgoszcz 2008.

Niwiński A., Środki informatyczne w katechetycznej działalności Kościoła, Kraków 2004.

Orzoł M., Znaczenie wspótczesnych technologii informacyjnych dla zarzadzania polskimi przedsiębiorstwami, http://www.ptzp.org.pl/files/konferencje/kzz/artyk_pdf_2010/ 117_Orzol_I.pdf [dostęp: 28.04.2015], s. 1-2.

Paja W., Technologie internetowe - wybrane zastosowania, Rzeszów 2012.

Panuś K., Zarys historii kaznodziejstwa w Kościele katolickim, cz. 1: Kaznodziejstwo w Kościele powszechnym, Kraków 1999.

Paweł VI, Adhortacja apostolska o ewangelizacji w świecie wspótczesnym „Evangelii nuntiandi", 8 grudnia 1975, tekst polski, Warszawa 1986.

Pismo Święte Starego i Nowego Testamentu w przekładzie z języków oryginalnych, opracował Zespół Biblistów Polskich z inicjatywy Benedyktynów Tynieckich, Poznań-Warszawa $1989^{4}$.

Sikorski W., Komputer, Warszawa 2010.

Sławiński H., Przygotowanie homilii i kazania za pomoca internetu, „Ateneum Kapłańskie" 149 (2007), z. 1, s. 125-132.

Sobór Watykański II, Konstytucja duszpasterska o Kościele w świecie wspótczesnym „Gaudium et spes”, 7 grudnia 1965 r., w: Sobór Watykański II, Konstytucje, dekrety, deklaracje, tekst polski, nowe tłumaczenie, Poznań 2002.

Sobór Watykański II, Konstytucja o liturgii świętej „Sacrosanctum concilium” (04.12.1963), w: Sobór Watykański II, Konstytucje, dekrety, deklaracje, tekst polski, nowe thumaczenie, Poznań 2002.

Stachowiak B., Technologie informacyjno-komunikacyjne w funkcjonowaniu uczelni wyzszych, Toruń 2012.

Staniek E., Kazanie w starożytności chrześcijańskiej, w: Fenomen kazania, red. W. Przyczyna, Kraków 1994, s. 19. 
Ścigała M., Technologie informacyjne determinanta innowacyjności: aktualny model organizacji, „Zeszyty Naukowe. Organizacja i Zarządzanie / Politechnika Śląska” 68 (2014), s. 413-423;

Technologia informacyjna w spoleczeństwie wiedzy, red. J. Trawka, Katowice 2005.

Technologie informacyjne a zmiany wspótczesnej edukacji, red. S. Kuruliszwili, Kraków 2014.

Technologie informacyjne dla spoleczeństwa, red. W. Chmielarz, T. Parys, Warszawa 2009.

Technologie informacyjne i komunikacyjne w edukacji dorostych: przewodnik dobrych praktyk, red. I. Moczydłowska, Siedlce 2012.

Technologie informacyjne w edukacji policjantów, red. A.W. Mitasa, Legionowo 2008.

Technologie informacyjne $w$ funkcjonowaniu organizacji: zarzadzanie $z$ wykorzystaniem multimediów, red. L. Kiełtyka, Toruń 2013.

Technologie informacyjno-komunikacyjne w edukacji XXI wieku, red. R. Wawer, M. Pakuła, Lublin 2014.

Technologie informacyjno-komunikacyjne w pracy stużb społecznych, red. E. Harlow, S.A. Webb, Warszawa 2014.

Technologie informacyjno-komunikacyjne w procesie ksztatcenia, red. J. Jędryczkowski, Jelenia Góra 2011.

Twardy J., Proces przygotowania homilii, „Roczniki Teologiczne” 61 (2014) z. 12, s. 73-87.

Wiszowaty E., Od kazania tematycznego do homilii, „Studia Warmińskie” 39 (2002), s. 385-394.

Żywczak K., Internet krok po kroku. Praktyczny poradnik, Poznań 2010. 